\title{
The effect of perennial ryegrass sowing date on endophyte presence and dry matter yield
}

\author{
J.R. CORKRAN, W.E.J. HENSON and G.A. KERR \\ NZ Agriseeds Ltd., 2547 Old West Coast Road, Christchurch 7671, New Zealand \\ jcorkran@agriseeds.co.nz
}

\begin{abstract}
The effect of perennial ryegrass sowing date on dry matter (DM) yield and endophyte presence in the resultant pasture was investigated in 2014. 'Trojan' perennial ryegrass with NEA2 endophyte was sown on three separate occasions (20 February, 20 March and 27 April 2014) into a Kaipaki peat loam soil in a replicated plot trial on a dairy farm near Cambridge, Waikato. The first two sowings were in dry conditions and neither showed any sign of germination until after $45 \mathrm{~mm}$ of rainfall on 4 April (43 days and 15 days after sowing, respectively). Endophyte infection in established plots was measured on 17 December 2014. Yield was also measured from sowing until no difference was seen between treatments, in October 2014. Percentage endophyte infection was not affected by sowing date. Establishment was significantly faster in the February and March sowings, prior to rain, and these produced ca. $2 \mathrm{t} \mathrm{DM} /$ ha more than the April sowing giving an estimated total profit advantage of $\$ 646 / \mathrm{ha}$.
\end{abstract}

Keywords: endophyte, Epichloë festucae var. lolii (formerly Neotyphodium lolii), perennial ryegrass, Lolium, seed storage, sowing date, NEA2

\section{Introduction}

In New Zealand farming systems, perennial ryegrass (Lolium perenne) is most often used in symbiotic association with the asexual fungi Epichloë festucae var. lolii (formerly Neotyphodium lolii), more commonly referred to as "endophyte". This endophyte lives as fungal hyphae within the aerial portion of the ryegrass plant (Schmid \& Christensen 1999) and can deter insect herbivory, discourage over-grazing, enhance drought tolerance, and therefore aid the overall persistence of its host (Easton 1999; Latch \& Christensen 1982; Popay \& Hume 2011). Endophyte survival in seed is critical to endophyte presence in the successive plant generation (Philipson \& Christey 1986; Schmid \& Christensen 1999).

The early endophyte strain found in New Zealand, subsequently called "standard" or "wild" endophyte, has been superseded by a range of newer endophyte strains including NEA2, AR37, AR1 and Endo5, which have differing levels of protection against insects but provide improved health and production of grazing animals over standard endophyte (Stewart et al. 2014).

The introduction of these selected endophytes to the New Zealand market has added complexity to plant breeding, commercial seed production and seed quality assurance (Rolston \& Agee 2007). When farmers buy seed of a grass/endophyte combination they expect a high level of endophyte viability (Rolston \& Agee 2007) not only in this seed, but also in the resultant pasture. Similar to germination, seed lines are tested for endophyte content, with a minimum level set by the New Zealand seed industry of $70 \%$ viable endophyte (Stewart et al. 2014).

Research on endophyte viability within ryegrass seed under differing storage conditions (Rolston et al. 1986; Tian et al. 2013) has shown that if low temperatures and relative humidity (low seed moisture content) are not maintained, endophyte viability generally declines more quickly than seed viability, leaving seed that will germinate but not contain endophyte (Hume et al. 2011; Rolston \& Agee 2007; Wheatley et al. 2007). During storage standard endophyte tends to be more stable within the host seed, than the newly selected strains. Tian et al (2013) used accelerated aging techniques and found more pronounced declines in stability of selected endophytes (AR1, AR37, NEA2, NEA3 and NEA6) in seed when compared with standard endophyte. Because of this most seed companies in New Zealand have invested heavily in cool storage (Stewart et al. 2014) to ensure seed is kept in optimum conditions (less than $4^{\circ} \mathrm{C}$ with low relative humidity (Tian et al. 2013)) to help ensure live endophyte level remains high within seed. Information is provided to farmers recommending that, prior to sowing, endophyte containing ryegrass seed should only be kept on farm for a short period in cool, dry conditions to minimise the chance of endophyte loss (Agriseeds 2015; PGGWrightsonSeeds 2015).

In many areas of New Zealand soil moisture levels can still be low when new pasture is sown, delaying the germination and emergence of seed. In this case, is there an effect on endophyte viability within the seed between sowing and germination in a hot, dry seedbed?

Sowing date can also influence dry matter (DM) yield of the resultant pasture. A Manawatu study by Hamilton-Manns et al. (1995) showed that yield declined by an average of $26 \mathrm{~kg} \mathrm{DM} / \mathrm{ha}$ with each day sowing was delayed past 23 February. In Canterbury, 


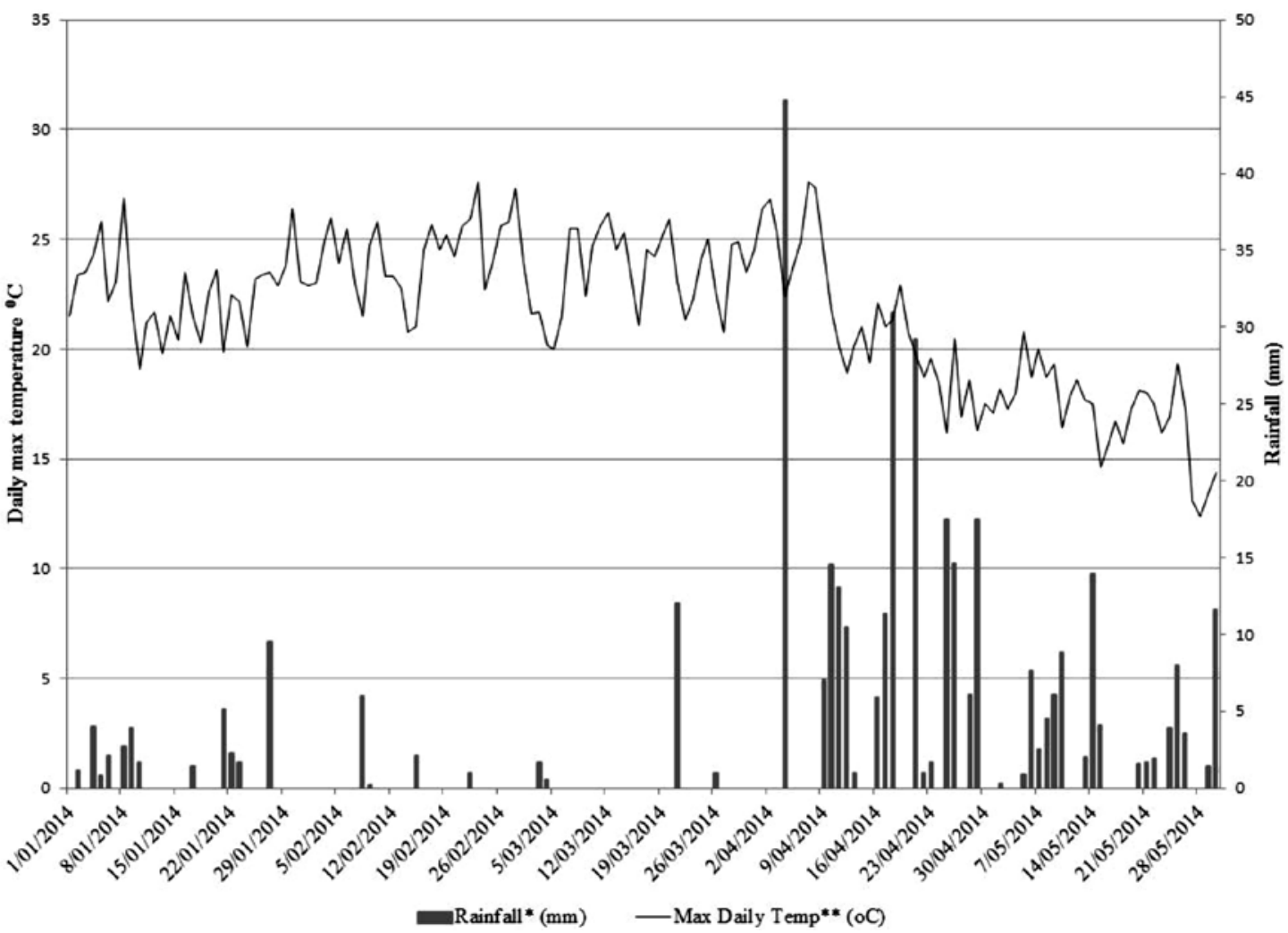

Figure $1 \quad$ Daily rainfall for Cambridge and maximum daily temperature data for Lake Karapiro 1 January $2014-31$ May 2014 (NIWA 2015a,b)

1 Both NIWA weather stations are within $10 \mathrm{~km}$ of the trial site. No maximum temperature data was available at the Cambridge site.

* Rainfall data from Cambridge weather station, representative of trial site

** Maximum daily temperature from Lake Karapiro weather station

Rolston \& Archie (2005) looked at the effect of sowing date on ryegrass seed crops at Lincoln, finding that herbage yields decreased by an average of $64 \mathrm{~kg} \mathrm{DM} /$ ha for each day that sowing was delayed through autumn. Early sown pastures can also have a thermal time advantage and compete better with weeds before the temperature drops (Moot et al. 2000).

The objective of this study was to investigate the effects of differing sowing dates on viable endophyte levels and yield of the resultant pasture in a replicated on-farm trial near Cambridge.

\section{Methods}

\section{Trial}

The trial was sown on a dairy farm at 3039 Te AwamutuCambridge Road $\left(37^{\circ} 95^{\prime} \mathrm{S}, 175^{\circ} 41^{\prime} \mathrm{E}\right)$. A dark Kaipaki peat loam soil was used in this study as this soil type is known to reach high temperatures in the summer and early autumn. Prior to the trial the paddock was cropped in summer turnips, and had also been used as a sacrifice paddock to stand off cows over summer and autumn immediately prior to drilling.
The Genstat 15 statistical programme was used to design a doubly-resolvable factorial trial layout, with $2.5 \mathrm{~m} \times 5 \mathrm{~m}$ plots and four replicates for each of three sowing dates (20 February, 20 March and 27 April 2014) and four sowing rates. Only the effects of sowing date are presented in this paper.

The trial was sown with the diploid perennial ryegrass cultivar 'Trojan' infected with NEA2 novel endophyte, a combination of several endophyte strains marketed under the NEA2 brand. 'Trojan' ryegrass is classified under Seed Certification as Lolium boucheanum due to a low level of tip awns (hairs) on its seed, however, it is marketed as a perennial ryegrass (Lolium perenne) as its performance and persistence best fit this description (Kerr et al. 2012). Seed laboratory results, from a grow-out test, showed the germination and viable endophyte levels of the seed line sown were $91 \%$ (standard error $\pm 2 \%$ ) and $88 \%$ (standard error $\pm 6 \%$ ), respectively.

Seed was sown at $20 \mathrm{~kg} / \mathrm{ha}$ using a small Oyjord 10 -coulter plot drill. No clover was sown. Soil temperature was assessed at the seed sowing depth of 2 
$\mathrm{cm}$ using a hand held soil thermometer at $10 \mathrm{am}$ on the day of each sowing.

Soil test results prior to the summer turnip crop reported a $\mathrm{pH}$ of 5.8 and Olsen $\mathrm{P}$ of 34 . No other soil test information was available. Lime at $2 \mathrm{t} / \mathrm{ha}$ was applied prior to the turnip crop. The trial paddock was an effluent paddock though no effluent was applied to the trial area after sowing. Fertiliser applied included $27 \mathrm{~kg} \mathrm{~N} / \mathrm{ha}$ and $30 \mathrm{~kg} \mathrm{P} / \mathrm{ha}$ applied as DAP after rain on May 14 2014. Urea at $80 \mathrm{~kg} / \mathrm{ha}(37 \mathrm{~kg} \mathrm{~N} / \mathrm{ha}$ ) was applied 26 August and 2 October 2014.

Herbicide was applied to the trial area after the first grazing for the February and March sown treatments, with $65 \mathrm{~g} / \mathrm{ha}$ of Preside ${ }^{\mathrm{TM}}$ ( $52 \mathrm{~g} / \mathrm{ha}$ of a.i. flumetsulam) and 3.5 litre/ha Select ${ }^{\mathrm{TM}}$ (375 g/litre MCPB plus $25 \mathrm{~g} /$ litre MCPA) to control broadleaf weeds.

\section{Forage yield cuts and endophyte}

Plots were assessed for yield on five occasions from 21 May until 16 October 2014, at which point there was no significant difference in yield between treatments for two consecutive harvests. Fresh weight yield was measured using a lawnmower to cut a single $5 \mathrm{~m} \times 0.5 \mathrm{~m}$ $\left(2.5 \mathrm{~m}^{2}\right)$ strip to a residual of $5 \mathrm{~cm}$. Harvests coincided with the time a farmer would be recommended to graze the new pasture at the 2.5-3 leaf stage (Donaghy et al. 2008; Fulkerson \& Donaghy 2001). Dry matter was not determined on the freshly cut material, as all plots contained the same cultivar, and a constant dry matter content of $16 \%$ was assumed for DM yield calculations.

Endophyte presence in the established ryegrass plants were assessed on 17 December 2014 using 50 random tillers from each of the eight replicated plots for each sowing date. Tillers were cut at ground level and assessed for viable endophyte using nitrocellulose membrane tissue-print immunoblot (Simpson et al. 2012).

Results of endophyte presence and herbage yield at different sowing dates were statistically analysed with Genstat 15 using an analysis of variance (ANOVA) and the least significant differences (LSD) for treatment differences at the $5 \%$ level.
Rainfall records used were from NIWA Cambridge station; C75944 $\left(37^{\circ} 90^{\prime} \mathrm{S}, 175^{\circ} 47^{\prime} \mathrm{E}\right)$ (NIWA 2015a) and maximum daily temperature was used from the Lake Karapiro NIWA station, C75955 (37 $92^{\prime}$ S, $175^{\circ} 54^{\prime} \mathrm{E}$ ) (NIWA 2015b) (Figure 1). Both weather stations are within $10 \mathrm{~km}$ of the trial site.

\section{Results}

In the Waikato, the 2013/14 season was officially declared a drought, with summer rainfall only $40-60 \%$ of the long term average, and very dry soil conditions (NIWA 2015a). There was little rainfall at Cambridge in late summer and early autumn (Figure 1). The first and second sowings on 20 February and 20 March showed no sign of germination until $45 \mathrm{~mm}$ of rainfall on 4 April (43 and 15 days after sowing, respectively). Peat soils can reach high temperatures. Soil temperatures at the depth of the sown seed were 49,42 and $27^{\circ} \mathrm{C}$ at 10 am on the day of sowing of the February, March and April treatments, respectively.

The earlier sown February and March treatments produced significantly more herbage than the April sowing $(\mathrm{P}<0.001)$ at ca. $2 \mathrm{t} /$ ha of extra DM from May to October 2014 (Table 1). Sowing dates did not differ in individual herbage yields after mid-September.

The proportion of endophyte-infected tillers as measured in established ryegrass plots in December did not differ statistically between the February $(73 \%)$, March (68\%) and April (68\%) sowing dates ( $\mathrm{P}=0.642)$.

\section{Discussion}

\section{Endophyte survival in soil}

The main purpose of this study was to investigate the survival of endophyte in seed in a hot, dry seed bed. Results from this trial showed that NEA2 endophyte in 'Trojan' ryegrass survived in the soil in an atypically dry autumn (Figure 1) with up to 43 days without significant rain, with soil temperatures up to $49^{\circ} \mathrm{C}$ at the sowing depth of $2 \mathrm{~cm}$. Given that the summer rainfall in Cambridge was only $40-60 \%$ of the long term average in 2014 (NIWA 2015a), this level of soil dryness provides a robust test of endophyte survival in seed for an extended period.

Table 1 Estimated dry matter (DM) yields from each cut and total up to 16 October from three sowing dates in 2014.

\begin{tabular}{|c|c|c|c|c|c|c|}
\hline \multirow[b]{2}{*}{ Date of sowing } & \multirow[b]{2}{*}{ 20-May } & \multicolumn{5}{|c|}{ DM yield (kg DM/ha) } \\
\hline & & 10-Jul & 11-Sep & 29-Sep & $16-O c$ & Total \\
\hline 20 February & $928 b^{1}$ & $2221 \mathrm{a}$ & 1267 a & 518 a & $934 \mathrm{a}$ & $5869 \mathrm{a}$ \\
\hline 20 March & $1082 \mathrm{a}$ & 2426 a & $1043 b$ & $506 a$ & $845 a$ & $5894 a$ \\
\hline 27 April & -2 & $1267 b$ & $1165 \mathrm{a}$ & $531 \mathrm{a}$ & 896 a & $3866 \mathrm{~b}$ \\
\hline LSD (5\%) & 133 & 228 & 223 & 115 & 195 & 449 \\
\hline Significance ( $P$ value) & 0.028 & $<0.001$ & 0.008 & 0.027 & 0.262 & $<0.001$ \\
\hline
\end{tabular}

1 Numbers within a column with the same letter are not significantly different.

2 Plots did not have sufficient herbage to harvest. 
Results show that there is no significant $(\mathrm{P}=0.642)$ difference in endophyte presence between different sowing date treatments, indicating that endophyte presence was not affected by hot soil temperatures or delayed germination in the trial.

There was a difference in the endophyte level of the field plots (mean of 69\%) and the laboratory result of the sown seed (88\%), the specific reason(s) for which is unknown. One likely factor is the potential for immunoblotting to underestimate the presence of endophyte in pastures with a proportion of drier and reproductive tillers. Immunoblotting relies on sufficient sap being extracted from a tiller onto the blotting paper. Therefore, if a tiller returns a negative endophyte result, the tiller either does not have endophyte, or insufficient sap was expelled from the tiller to register a positive result. While a concerted effort was made to measure young non-reproductive tillers, drier and more lignified ryegrass at the time of testing made it more difficult to extract sap from tillers.

\section{Yield advantage of early sowings}

Sowing early in dry autumn conditions, prior to rain, can give faster pasture establishment and greater DM yield through winter and spring (Hamilton-Manns et al. 1995; Rolston \& Archie 2005). These previous results are supported by the results of this trial, with an extra 2 t DM/ha produced during the autumn-winter period by the two early sowings. The size of this advantage will vary season to season. Sowing early should also improve pasture persistence through producing larger, bettertillered plants prior to a possible summer dry period.

February and March treatments were ready for their first cut 46 days after the 4 April rain. April treatments were not ready for their first cut for a further 50 days (96 days after rain). March and April treatments had significantly more herbage (ca. $1000 \mathrm{~kg} \mathrm{DM} /$ ha) in July compared with the April sown treatments $(\mathrm{P}<0.001)$ (Table 1$)$. Viability of seed and seed vigour was therefore still high in earlier sown treatments despite sowing into seedbeds with high $\left(>40^{\circ} \mathrm{C}\right)$ soil temperatures at sowing depth.

Using the DairyNZ Forage Value Index (FVI), profit values for seasonal DM yield for the Upper North Island, the value of forage for each sowing date can be estimated (Chapman et al. 2012, 2013; DairyNZ 2015). From May to October the extra $2016 \mathrm{~kg} \mathrm{DM} / \mathrm{ha}$ from the February and March sowings would provide an estimated average profit of $\$ 646 /$ ha in a dairy farm system, or just over $\$ 0.30 / \mathrm{kg} \mathrm{DM}$, over the later April sowing. This has been calculated in Table 2 through multiplying the DM yields at each cut (Table 1) by the FVI profit value (ranging from $\$ 0.48 / \mathrm{kg}$ DM in early spring to $\$ 0.22 / \mathrm{kg}$ DM in late spring (DairyNZ 2015)) for that cut. The advantage of the earlier sowings equated to one extra grazing before winter (20 May in Table 1), as well as more DM in the second grazing, a time when additional feed is valuable due to lower pasture growth rates (10 July in Table 1).

\section{Conclusion}

Sowing early (1 March onwards) has several advantages: the seed is in the ground and ready to germinate as soon as adequate moisture is available; the viability of seed and endophyte levels remains high; and sowing early can result better pasture establishment and higher yields.

Table 2 Total profit of pasture grown (\$/ha) in a dairy farm system at each cut, total up to October and the advantage of Feb/ March sowing vs April sowing, based on 2014/2015 Forage Value Index (FVI) Economic Value (EV) for pastures

\begin{tabular}{|c|c|c|c|c|c|c|}
\hline \multirow[b]{2}{*}{ Sowing date } & \multicolumn{6}{|c|}{ Total \$/ha from pasture } \\
\hline & 20-May & 10-Jul & 11-Sep & 29-Sep & $16-$ Oct & Total \\
\hline 20 February & 278 & 746 & 549 & 114 & 206 & 1,893 \\
\hline 20 March & 324 & 815 & 452 & 111 & 186 & 1,888 \\
\hline 27 April & 0 & 426 & 505 & 117 & 197 & 1,245 \\
\hline $\begin{array}{l}\text { Average extra profit } \\
\text { Feb/March vs. April (\$/ha) }\end{array}$ & 301 & 355 & -4 & -4 & -1 & 646 \\
\hline Average $\mathrm{EV}^{1} \$ / \mathrm{kg} \mathrm{DM}$ & 0.30 & 0.34 & 0.43 & 0.22 & 0.22 & $0.30^{3}$ \\
\hline $\begin{array}{l}\text { Seasonal proportion }{ }^{2} \text { for } \\
\text { FVI EV }\end{array}$ & $\begin{array}{c}100 \% \text { winter } \\
(\$ 0.30)\end{array}$ & $\begin{array}{c}80 \% \text { winter } \\
(\$ 0.30), 20 \% \\
\text { early spring } \\
(\$ 0.48)\end{array}$ & $\begin{array}{c}82 \% \text { early spring } \\
(\$ 0.48), 18 \% \\
\text { late spring } \\
(\$ 0.22)\end{array}$ & $\begin{array}{c}100 \% \text { late } \\
\text { spring }(\$ 0.22)\end{array}$ & $\begin{array}{c}100 \% \text { late } \\
\text { spring }(\$ 0.22)\end{array}$ & \\
\hline
\end{tabular}

\footnotetext{
${ }^{1}$ Average Economic Value. For July and September cuts; growth straddled two FVI seasons, so an average FVI profit value was calculated based on the proportion of days of pasture growth in each season

2 Relevant FVI seasons \& EV for upper North Island defined as: Winter $\$ 0.30 / \mathrm{kg} \mathrm{DM}=$ May/June; Early Spring $\$ 0.48 / \mathrm{kg} D M=\mathrm{July} / \mathrm{Aug}$; Late Spring $\$ 0.22 /$ $\mathrm{kg} \mathrm{DM}=$ Sep/Oct

${ }^{3}$ Average EV for pasture over the 5 cuts
} 


\section{ACKNOWLEGEMENTS}

David Baird for trial design as well as assistance/ checking of statistical analysis. Barry Henderson who helped us in the field. Colin Eady for the help with science and proof reading. John and Jackie Cook, on whose farm the trial was run. The technicians in the seedlab at Agriseeds HQ in Canterbury. Reuben Carter for early work on the trial.

\section{REFERENCES}

Agriseeds 2015. Storing seed with endophyte. 2015. http://www.agriseeds.co.nz/sheep-beef-pasture/ pasture-management/storing-seed-with-endophyte. htm. Accessed: 15/05/2015

Chapman, D.; Bryant, J.; McMillan, W.; Khaembah, E. 2012. Economic values for evaluating pasture plant traits. Proceedings of the New Zealand Grassland Association 74: 209-216

Chapman, D.F.; Bryant, J.R.; Kerr, G.A.; Judson, G.; Cookson, T.; Edwards, G.R.; McMillan, W.H. 2013. Economic values for perennial ryegrass traits in New Zealand dairy farm systems. pp. 822-823 In: Proceedings of the 22nd International Grasslands Congress.

DairyNZ 2015. FVI seasonal economic values. http:// www.dairynz.co.nz/feed/cultivar-selection/aboutfvi/economic-values/ Accessed: 20/05/2015

Donaghy, D.; Turner, L.; Adamczewski, K. 2008. Effect of defoliation management on water-soluble carbohydrate energy reserves, dry matter yields, and herbage quality of tall fescue. Agronomy Journal 100: 122-127.

Easton, H. 1999. Endophyte in New Zealand ryegrass pastures, an overview. Ryegrass endophyte: an essential New Zealand symbiosis. Grassland Research and Practice Series 7: 1-9.

Fulkerson, W.; Donaghy, D. 2001. Plant-soluble carbohydrate reserves and senescence - key criteria for developing an effective grazing management system for ryegrass-based pastures: a review. Animal Production Science 41: 261-275.

Hamilton-Manns, M.; Ritchie, W.R.; Baker, C.J.; Kemp, P.D. 1995. Effects of sowing date on ryegrass and tall fescue establishment by direct-drilling. Proceedings Agronomy Society of New Zealand 25: 43-46

Hume, D.; Schmid, J.; Rolston, M.; Vijayan, P.; Hickey, M. 2011. Effect of climatic conditions on endophyte and seed viability in stored ryegrass seed. Seed Science and Technology 39: 481-489.

Kerr, G.; Chapman, D.; Thom, E.; Matthew, C.; Van Der Linden, A.; Baird, D.; Johnston, E.; Corkran, J. 2012. Evaluating perennial ryegrass cultivars: improving testing. Proceedings of the New Zealand Grassland Association 74: 127-136.
Latch, G.; Christensen, M. 1982. Ryegrass endophyte, incidence, and control. New Zealand Journal of Agricultural Research 25: 443-448.

Moot, D.; Scott, W.; Roy, A.; Nicholls, A. 2000. Base temperature and thermal time requirements for germination and emergence of temperate pasture species. New Zealand Journal of Agricultural Research 43: 15-25.

NIWA 2015a. Cambridge rainfall data, station: C75944. In: Cambridge rainfall data 01.01.2014 - 31.05.2014. 2015: http://www.niwa.co.nz/climate/our-services/obtainingclimate-data-from-niwa Accessed: 02/07/2015

NIWA 2015b. Lake Karapiro daily temperature data, station: C75955. In: Daily maximum temperaure data 01.01.2014 - 31.05.2014. 2015: http://www. niwa.co.nz/climate/our-services/obtaining-climatedata-from-niwa Accessed: 02/07/2015

PGGWrightsonSeeds 2015. Endophyte FAQ 2015. http://www.pggwrightsonseeds.com/technical/ endophyte-faq/ Accessed: 15/05/2015

Philipson, M.N.; Christey, M.C. 1986. The relationship of host and endophyte during flowering, seed formation, and germination of Lolium perenne. New Zealand Journal of Botany 24: 125-134.

Popay, A.; Hume, D. 2011. Endophytes improve ryegrass persistence by controlling insects. Pasture Persistence Symposium. Grassland Research and Practice Series. 15: 149-156

Rolston, M.; Agee, C. 2007. Delivering quality seed to specification - the USA and NZ novel endophyte experience. Proceedings of the 6th International Symposium on Fungal Endophytes of Grasses. New Zealand. Grassland Research and Practice Series 13: 229-231.

Rolston, M.; Archie, W. 2005. Effect of late autumn sowing dates on ryegrass seed yields. Proceedings of the Agronomy Society of New Zealand 35: 97-103

Rolston, M.P.; Hare, M.D.; Moore, K.K.; Christensen, M.J. 1986. Viability of Lolium endophyte fungus in seed stored at different moisture contents and temperatures. New Zealand Journal of Experimental Agriculture 14: 297-300.

Simpson, W.R.; Schmid, J.; Singh, J.; Faville, M.J.; Johnson, R.D. 2012. A morphological change in the fungal symbiont Neotyphodium lolii induces dwarfing in its host plant Lolium perenne. Fungal Biology 116 : 234-240.

Schmid, J.; Christensen, M.J. 1999. Ryegrass endophyte: host/fungus interaction. Ryegrass endophyte: An essential New Zealand symbiosis. Grassland Research and Practice Series 7: 101-106.

Stewart, A.; Kerr, G.; Lissaman, W.; Rowarth, J. 2014. Endophyte in ryegrass and tall fescue. Pasture and forage plants for New Zealand. Grassland Research and Practice Series 8: 66-77 
Tian, P.; Le, T.-N.; Smith, K.F.; Forster, J.W.; Guthridge, K.M.; Spangenberg, G.C. 2013. Stability and viability of novel perennial ryegrass hostNeotyphodium endophyte associations. Crop and Pasture Science 64: 39-50.
Wheatley, W.; Kemp, H.; Simpson, W.; Hume, D.; Nicol, H.; Kemp, D.; Launders, T. 2007. Viability of endemic endophyte (Neotyphodium lolii) and perennial ryegrass (Lolium perenne) seed at retail and wholesale outlets in south-eastern Australia. Seed Science and Technology 35: 360-370. 